\title{
Indigenous Development of Automobile Radiator using CFD \\ ${ }^{1}$ G.Senthilkumar, ${ }^{2}$ S.Ramachandran, ${ }^{3}$ M.Purusothaman \\ Department of Mechanical Engineering, \\ Sathyabama University
}

\begin{abstract}
The aim of this project is to design and optimize the existing automobile radiator. The entire analysis is carried out using CFD (Computational Fluid Dynamics) with FLUENT (6.0.) as software. The main objective is to design the automobile radiator with surface area density (SAD) greater than 1000 $\mathrm{m}^{2 /} / \mathrm{m}^{3}$ with increased heat transfer coefficient, rate of Heat transfer, reduced cost and reduced weight using CFD. Suitable modifications are to be incorporated depending on the requirements.
\end{abstract}

Key Words- CFD, FLUENT, SAD

\section{INTRODUCTION}

Car radiator is one of the most important operating components of our automobile. Responsible for keeping our automobile's engine at a safe operating temperature, a malfunctioning automotive radiator could mean big trouble for us if we do not seek professional mechanical attention immediately. Auto radiator and truck radiator problems can often develop without we even knowing it, with small particles of dirt and rust clogging up the essential elements, preventing our car radiator from being able to cool our engine properly. If this happens, our vehicle will over heat, potentially leaving us stranded.

\section{A. Chanracteristics}

Color is not always a reliable indicator of the coolant's family. There are green conventional and hybrid products, and we've even seen one green carboxylate. There are yellow coolants in all three families. So far, we haven't seen any orange conventional products but there are both carboxylates and hybrids in orange. All can be found in shades of red and blue. To make matters worse, most of the colors change with time, drawing closer together and making matching even more difficult.

\section{DESIGN DETAILS}

The automobile radiator is first designed using GAMBIT with following design specifications. Length $(\mathrm{L})=600 \mathrm{~mm}$ Width
(B)
$=750 \mathrm{~mm}$
Height $(\mathrm{H})$
$=75 \mathrm{~mm}$

With tube specification as follows:

Length of each tube $=1 \mathrm{~mm}$

Width of each tube $=3 \mathrm{~mm}$

Total number of tubes $=(24 \times 12)$
The inlet and outlet pipes through which water is flowing is designed with diameter of $\mathrm{d}=70 \mathrm{~mm}$ and Length $1=200$ $\mathrm{mm}$

\section{HEAT TRANSFER CALCULATIONS}

\section{A. Heat transfer on air side}

1.Q $=\mathrm{h}$ a $\Delta \mathrm{T}$

For air heat transfer coefficient $(\mathrm{h})=20 \mathrm{w} / \mathrm{m}^{2} \mathrm{k}$

Heat transfer

area $=(2 \times 0.6 \times 0.75)+(2 \times 0.075 \times 0.6)+(2 \times 0.75 \times 0.075)=1.1025 \mathrm{~m}^{2}$.

$\Delta \mathrm{T}=40 \mathrm{c}$

$\mathrm{Q}=20 \times 1.1025 \times 40=882 \mathrm{~W}$

B. Heat transfer on water side

2.Q $=\mathrm{M} \mathrm{C}_{\mathrm{P}} \Delta \mathrm{T}$

$882=\mathrm{M} \mathrm{x} 4187 \times 45$

$\mathrm{M}=0.00468 \mathrm{~kg} / \mathrm{s}$

C. Mass of water through each tube $(\mathrm{m})=\rho \mathrm{A} \mathrm{V}$

Area $(\mathrm{A})=3 \times 1=3 \mathrm{~mm}^{2}$

Density of water $=1000 \mathrm{~kg} / \mathrm{m}^{3}$

$0.00468=1000 \times 3 \times e-6 \times$ V

$\mathrm{V}=1.56 \mathrm{~m} / \mathrm{s}$

D. Reynolds number $(\mathrm{Re})=\mathrm{VD} / \mathrm{v}=1.56 \mathrm{x} 3 \mathrm{e}-3 / \mathrm{o} .61225 \mathrm{xe}-6$ $=7644$ Total volume $(\mathrm{V})=1 \mathrm{xbxw}$

$=0.6 \times 0.75 \times 0.075$

$=0.03375 \mathrm{~m}^{3}$

E. Heat release rate per unit volume $(\mathrm{Q} / \mathrm{V})=882 / 0.03375=$ $26133.33 \mathrm{w} / \mathrm{m}^{3}$

Friction factor $(\mathrm{f})=0.079 / \mathrm{Re}^{0.25}=0.079 / 7644^{0.25}=0.0084$

Pressure loss on tube side $4 .(\Delta \mathrm{T})=4 \mathrm{f} \quad \mathrm{V}^{2} / 2 \mathrm{~g} \quad \mathrm{D}=$ $4 \mathrm{x} 0.008 \mathrm{x} 0.75 \mathrm{xV}^{2} / 19.62 \times 3 \mathrm{e}-3$

$=0.43 \mathrm{~V}^{2}$ 


\section{DESIGN USING CFD}

Fig.1 shows the static pressure drop of water with coolant from the inlet to outlet. The pressure decreases from 191 Pascal to nearly vacuum at the outlet. Fig 2 illustrates the velocity vector changes from $1.93 \mathrm{e}-3$ to $1.83 \mathrm{e}-7$ of coolant . The very slow movement of coolant increases the time of contact between the two fluids resulting in increased heat transfer. In Fig.3 at inlet and outlet of the radiator, the velocity is different from at the porous media. To create turbulence, this increases the rate of heat transfer from water to

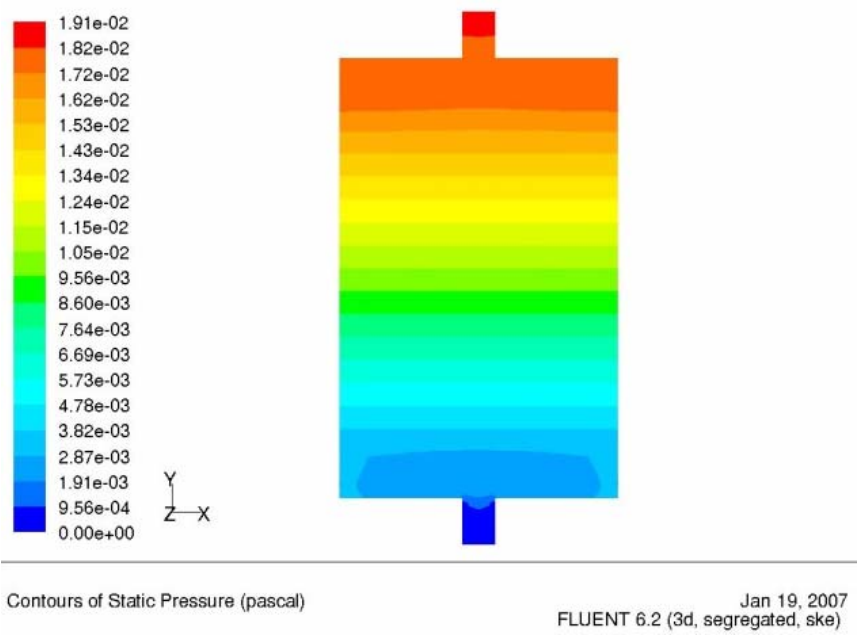

Figure.1Static Pressure drop of water

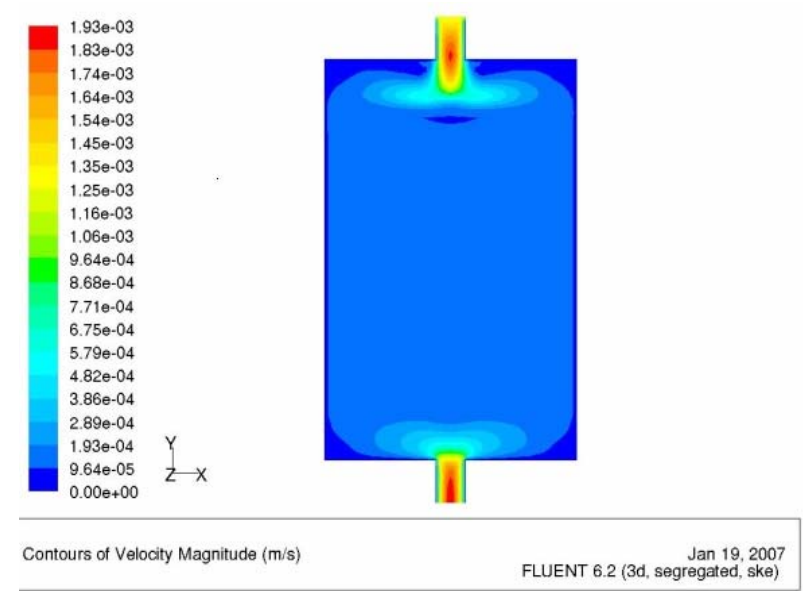

Figure.2Velocity magnitude on water side

Fig.3 Path line variation on water side air. In Fig 4 Using GAMBIT the given model is subjected to discretization using Hexa mesh type of Mesh Generation with interval count of 10 . For fine mesh configurations copper mesh is preferred. The mesh is regenerated using above procedure. Fig 5. Shows the variation of water temperature from inlet to radiator to outlet. The tempmperature of water decreases from $353 \mathrm{k}\left(80^{\circ} \mathrm{c}\right)$ to $308 \mathrm{k}\left(35^{\circ} \mathrm{c}\right)$ in order to avoid the overheating problems.

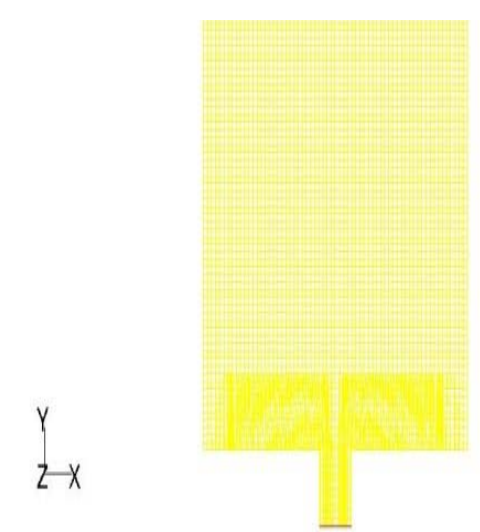

Grid $\operatorname{Jan} 19,2007$ FLUENT 6.2 (3d, segregated, ske)

Figure.4 Grid generation ion water side
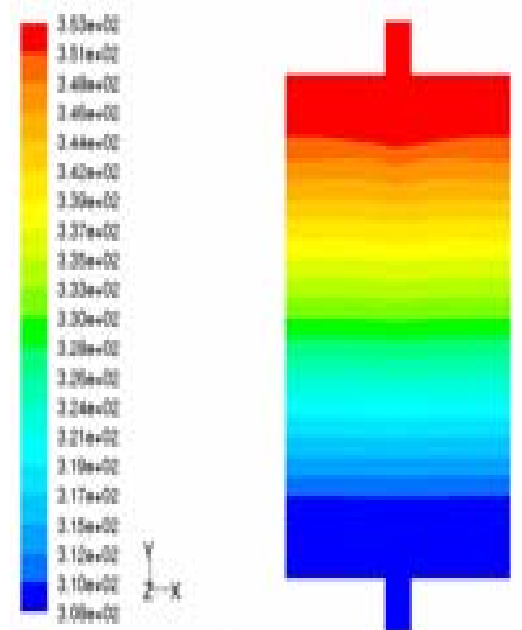

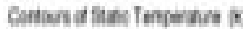

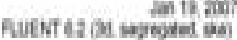

Figure.5 Static Temperature drop on water side 


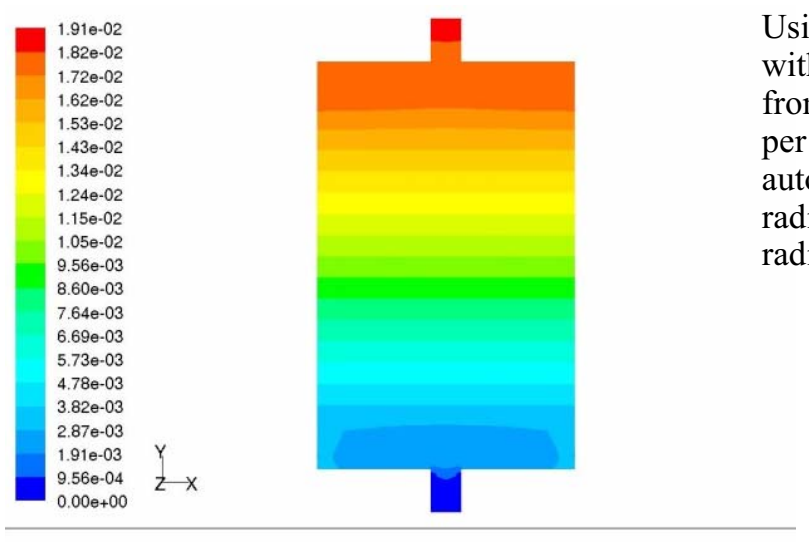

Contours of Static Pressure (pascal)

gure.6 Static Pressure rise of air

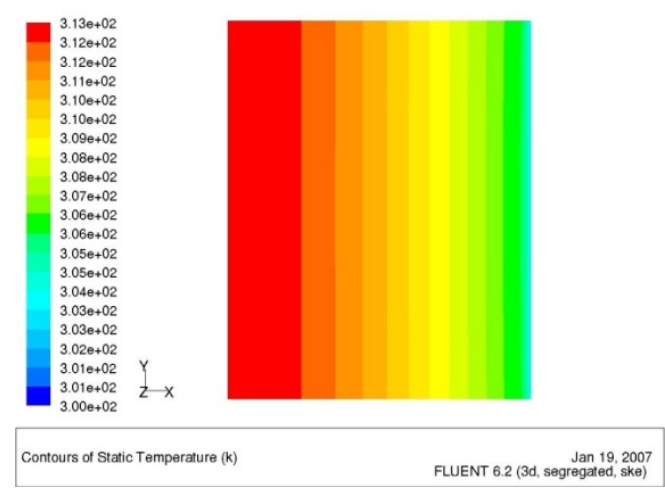

Figure.7 Static Temperature rise of air

Fig. 7 shows the temperature of air increases from $302 \mathrm{k}\left(29^{\circ} \mathrm{c}\right)$ to $313 \mathrm{k}\left(40^{\circ} \mathrm{c}\right)$ from inlet to outlet with cross flow conditions.

\section{D ESIGN SPECIFICATIONS}

TABLE I

FLOW CONDITIONS

\begin{tabular}{|c|c|c|c|c|c|}
\hline$U^{F L}$ & $\begin{array}{c}\text { INLET } \\
\text { TEMPERA } \\
\text { TURE } \\
{ }^{o} C\end{array}$ & $\begin{array}{l}\quad \text { OUTR } \\
\text { LET } \\
\text { TEMPERA } \\
\text { TURE } \\
\quad{ }^{o} \mathrm{C}\end{array}$ & 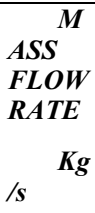 & $\begin{array}{c}\text { VELO } \\
\text { SITY } \\
m / s\end{array}$ & $\begin{array}{l}\text { HEAT } \\
\text { TRANS } \\
\text { FER } \\
\text { AREA } \\
\qquad m^{2}\end{array}$ \\
\hline $\begin{array}{l}\text { WA } \\
\text { TER } \\
\text { BLEND } \\
\text { ED } \\
\text { WITH } \\
\text { COOLA } \\
\text { NT }\end{array}$ & 80 & 35 & $46^{0.0}$ & ------ & $486^{0.86}$ \\
\hline
\end{tabular}

RESULTS AND DISCUSSIONS
Using FLUENT as a tool the Automobile radiator is designed withabove design specifications with surface area density increased fro from $1000 \mathrm{~m}^{2} / \mathrm{m}^{3}$ to $1500 \mathrm{~m}^{2} / \mathrm{m}^{3}$. Hence more heat is Tran transferred per unit volume thereby decreasing the size of exist existing automobile radiators with consequent reduction in the cost size of the radiator. This will be a improved solution for the problems faced by the radiator manufacturers.

TABLE 2 PARAMETRIC STUDIES

\begin{tabular}{|c|c|c|c|c|c|c|}
\hline \multirow{2}{*}{$\begin{array}{l}\text { Para } \\
\text { meters }\end{array}$} & \multicolumn{2}{|c|}{ CS: $1 \times 3$} & \multicolumn{2}{|c|}{$C S: 2 \times 3$} & \multicolumn{2}{|c|}{ CS : D3 } \\
\hline & r Wate & ir $\quad A$ & r Wate & $\begin{array}{ll} & \mathbf{A i}\end{array}$ & ter & ir $\quad$ A \\
\hline$(\mathrm{K})^{\mathrm{T} 1}$ & 353 & $00^{3}$ & 353 & 0 & 353 & $00^{3}$ \\
\hline$(\mathrm{K})^{\mathrm{T} 2}$ & $67 \begin{array}{ll}308.0 \\
67\end{array}$ & $12.93^{3}$ & 307.9 & $3.18^{31}$ & $.94^{307}$ & $13.36^{3}$ \\
\hline (K) ${ }^{\Delta} \mathrm{T}$ & 44.93 & $2.93^{1}$ & 45.05 & $18^{13}$ & $06^{45 .}$ & $3.36^{1}$ \\
\hline${ }_{(\mathrm{Pa})}{ }^{\Delta} \mathrm{P}$ & $36^{0.007}$ & $5.83^{1}$ & $183^{0.008}$ & $25^{3.7}$ & $189^{0.0}$ & $.13^{1}$ \\
\hline$(\mathrm{m} / \mathrm{s}){ }^{\text {Vel }}$ & $15^{0.001}$ & $77 \quad$ & 0.001 & 0.7 & $01 \quad 0.0$ & .9 \\
\hline \begin{tabular}{lc}
\multicolumn{2}{c}{ Mass } \\
flow rate \\
$\mathrm{Kg} / \mathrm{s}$
\end{tabular} & $16^{0.001}$ & $062^{0 .}$ & $16^{0.001}$ & $62^{0.0}$ & $0116^{0.0}$ & $.062^{0}$ \\
\hline$(\mathrm{W})^{\mathrm{Q}^{\text {act }}}$ & $\begin{array}{ll} & 218.8 \\
0 & \end{array}$ & - & 218.8 & - & $.24^{218}$ & - \\
\hline$(\mathrm{W})^{\mathrm{Q}_{\max }}$ & $5863^{255.9}$ & - & $5863^{255.9}$ & - & $\begin{array}{r}255 \\
.95863\end{array}$ & - \\
\hline$€$ & 0.85 & - & 0.855 & - & $526^{0.8}$ & - \\
\hline $\begin{aligned} & \text { SAD } \\
\left.\mathrm{m}^{3}\right) & \left(\mathrm{m}^{2} /\right.\end{aligned}$ & & $\begin{array}{r}9 \\
72.87\end{array}$ & & $00.03^{10}$ & & $66^{9}$ \\
\hline
\end{tabular}

\section{CONCLUSION}

The radiator size is reduced without affecting the heat transfer characteristics with improved rate of heat transfer. Depending on the requirements suitable modifications need to be incorporated thereby making the design more indigenous both from design point of view and economical point of view.

\section{REFERENCES}


[1] W.M. Rohsenhow, J.P. Hartnett, Y.I. Cho, Handbook of Heat Transfer, 3rd ed., Mc-Graw Hill, New York, 1998.

[2] R.M. Maglik, A.E. Bregles, Heat transfer and pressure drop correlations for the rectangular offset-strip-fin compact heat exchanger, Exp. Therm. Fluid Sci. 10 (1995) 171-180.
[3] W.M. Kays, A.L. London, Compact Heat Exchangers, 3rd ed., Mc-Graw Hill, New York, 1984.

[4] M. Yaghoubi, M. Rahnema, Numerical study of turbulent flow and heat transfer from an array of thick plates, Int.J. Therm. Sci. 39 (2000) 213 224. 